\title{
New Jews in Amsterdam: Some Social Aspects Reflected in the Thesouro dos Dinim by Menasseh ben Israel
}

\author{
Aliza Moreno-Goldschmidt
}

The main goal of the present study is to analyze selected excerpts from Menasseh ben Israel's Thesouro dos Dinim in order to extract his personal approach regarding former conversos who joined the Amsterdam Jewish community, as well as those who remained in the Lands of Idolatry. ${ }^{1}$ In order to understand the relevant background, the paper will include a brief description of the genre, that is to say, the halakhic manuals in Spanish and Portuguese published during the sixteenth and seventeenth centuries. It will also present a concise account of the changes in the halakhic status of the former conversos until the time of Menasseh ben Israel.

Menasseh ben Israel, one of seventeenth-century Jewish Amsterdam's most prominent figures, has also been one of its most studied. However, his halakhic work Thesouro dos Dinim, considered by some to be one of his least original or innovative writings, has aroused little interest. Modern scholars share this disinterest, but it also afflicted Menasseh ben Israel's contemporary colleagues. As Asa Kasher demonstrated, in contrast to the reputation that Menasseh ben Israel gained among non-Jewish intellectuals (who were obviously uninterested in his Jewish legal writings), his reputation as a legal scholar among the rabbinical leaders of his time was hardly outstanding. ${ }^{2}$ Nevertheless, whatever his rabbinical colleagues may have thought, the actual impact of Menasseh's work within the Jewish world — as a writer and communal religious leaderwas significant especially among the New Christians who returned to Judaism in Amsterdam and elsewhere in the Western Sephardic diaspora. Even if his halakhic work (specifically, his Thesouro dos Dinim) fails to be one of the most outstanding halakhic essays of his time, it should be a primary source for the study of the social and religious history of his day. Just as Sina Rauschenbach

1 The common term used at the time referring to those lands where the practice of Judaism was prohibited, and in particular Spain, Portugal and their colonies.

2 Asa Kasher, "How Important was Menasseh ben Israel?" in Menasseh ben Israel and His World, ed. Yosef Kaplan, Henry Méchoulan and Richard H. Popkin (Leiden: Brill, 1989), 220.

(C) ALIZA MORENO-GOLDSCHMIDT, 2019 | DOI:10.1163/9789004392489_019

This is an open access chapter distributed under the terms of the prevailing CC-BY-NC License at the time of publication. 
considers Menasseh's theological writings his method for mediating Jewish knowledge to the non-Jewish intellectuals, ${ }^{3}$ I would propose that Thesouro dos Dinim was Menasseh ben Israel's method of mediating Jewish practice to the former conversos who returned to Judaism.

Were we to ask the author, he would probably also judge Thesouro dos Dinim one of his less original works. In fact, in the book Menasseh explicitly declares his commitment to the rabbinic tradition, asserting that his only intention is to facilitate traditional Jewish practice by writing a book in both the language and style most accessible to his community. Many of his readers only adopted normative Judaism as adults after they arrived from the Iberian Peninsula. In contrast to other philosophical and mystical fields in which Menasseh ben Israel, as Yosef Dan stated, "chose in complete freedom whatever suited him, and rejected other elements,"4 in the realm of Jewish law he was uncompromisingly loyal to traditional Jewish law as he understood it. He had neither any intention nor ambition to propose even the slightest change or innovation.

So, if Menasseh ben Israel did not intend to write an original work, how can we extricate his own voice from the text - a text that was merely meant to translate existing Jewish practice into a language his community members could understand? Although Menasseh did not state what were his rabbinical sources and did not openly proclaim that the Thesouro dos Dinim was largely a literal translation or adaptation of Yosef Caro's Shulhan Arukh ${ }^{5}$ into Portuguese, a comparison between the two texts leads to the undeniable conclusion that this was his main source. In fact, it is interesting that he did not mention even a single time in any of the five parts of the Thesouro, either the Shulhan Arukh or its author Yosef Caro. ${ }^{6}$ Probably by the time Menasseh ben Israel wrote this work, the halakhic authority of the Shulhan Arukh was so spread in his cultural

3 Sina Rauschenbach, "Mediating Jewish Knowledge: Menasseh ben Israel and the Christian Respublica litteraria," Jewish Quarterly Review 102, no. 4 (2012): 561-88.

4 Yosef Dan, "Menasseh ben Israel: Attitude Towards the Zohar and Lurianic Kabbalah," in Menasseh ben Israel and His World, ed. Yosef Kaplan, Henry Méchoulan, and Richard H. Popkin (Leiden: Brill, 1989), 201.

5 The Shulhan Arukh is a practical and detailed manual of Jewish law published in Safed in 1565 by Rabbi Yosef Caro in Hebrew. Since its publication, and with the additions made by Rabbi Moshe Isserles known as the Mapah (that include the Ashkenazic customs, in addition to the Sephardic ones), the Shulhan Arukh became the supreme halakhic authority in the traditional Jewish world, a reality that continues to the present day.

6 In contrast, the author did mention, on few occasions, other rabbinical authorities, mainly Maimonides. See for example, Thesouro dos Dinim, Part IV, Cap. IV; Part v, Cap. IV; Part v, Cap. XXviII. 
and social context that the author felt no need to state what his main source was, but took it for granted that the readers will be aware of this fact.

The present study will be based on a thorough comparison of Thesouro dos Dinim and its main source, the Shulhan Arukh. Since we are trying to extract Menasseh ben Israel's voice, any part of the text that was translated from the Shulhan Arukh won't be useful to us. On the contrary, I will take into account only those parts that differ from Yosef Caro's work, that is to say, any additions or omissions and the cases in which the author utilizes a Jewish source that is not the Shulhan Arukh (cases in which it will be relevant to ask, what were Menasseh's reasons for choosing a different source?).

As Yosef Dan has systematically demonstrated, ${ }^{7}$ if we can determine Menasseh ben Israel's source, we can also learn from his silences. In some contexts, the decision of the Thesouro dos Dinim's author not to include a specific subject can lead us to important conclusions. However, this methodological tool must be used cautiously so as to avoid unfounded speculation. Therefore, I will only point out a few of his omissions and will focus primarily on his additions.

Halakhic Manuals in Ladino, Portuguese, and Spanish

Before beginning the textual analysis, it is also important to understand the sixteenth-century intellectual context of Thesouro dos Dinim and other similar period works. Menasseh ben Israel was neither the first, nor the last, author to publish halakhic manuals in the vernacular in the Eastern and Western Sephardic diasporas. In fact, the publication of various halakhic texts in Ladino, Spanish, and Portuguese may be considered one of the peculiarities of those communities, during a period when halakhic literature was exclusively published in Hebrew or Aramaic in other Jewish centers.

The oldest work of this kind was a translation into Ladino of extracts from Yosef Caro's Shulhan Arukh under the name Meza de el Alma by Meir Ben Shmuel ben Ban Benst (Benbeniste), ${ }^{8}$ published in Salonica in 1568 - around a decade after the Shulhan Arukh's first publication, while Caro was still alive-and reprinted in Venice in 1602 . This was not only the first translation

7 Dan compares Menasseh ben Israel's Nishmat Hayyim with the concepts of the Zohar, and reconstructs its mystical views pointing out the ideas that were adopted from the Zohar and those that were omitted as well. See Dan, "Menasseh ben Israel," 200-2.

8 See Dov Cohen, "The Ladino Bookshelf: Research and Mapping," (Hebrew) PhD diss., BarIlan University, 2011, 178-86. 
into Ladino, but the very first translation of the Shulhan Arukh into any other language. In accord with the norms and customs prevailing in the Ottoman Empire's Sephardic publishing world, this Ladino edition was printed in Hebrew characters. ${ }^{9}$ The selections included in this lengthy work are very much a literal, however sometimes partial, shortened or paraphrased ${ }^{10}$ translation of its source. In 16og, Moses Altaras published the Libro de Mantenimiento de la Alma in Venice. This work seems to be a revised edition of the Mesa de el Alma ${ }^{11}$ the main difference being the use of Latin characters. ${ }^{12}$

Isaac Athias, who was a religious leader of Hamburg's Portuguese congregation and later settled in Italy, published his Tesoro de Preceptos in Venice in 1627. It was reprinted in Amsterdam in 1649. This book, written in Spanish, details the 613 Jewish precepts, that is to say, the Jewish tradition's 613 biblical commandments. This text analyzes each precept and its significance. As stated in his prologue, Athias bases his book on Maimonides's Sefer ha-Mitzvot, in terms of, among other things, the enumeration, organization, and division of the contents into positive and negative commandments. In his introduction,

$9 \quad$ As mentioned by Levi, the Jews in the Ottoman Empire regularly used both Hebrew and Ladino, but for different purposes. While Hebrew was the language used for religious, liturgical, legal, and official community issues, Ladino was the spoken language used in informal, family, and commercial contexts. In fact, during the first two centuries after the expulsion there were almost no Ladino publications, but a few books and translations of the Bible published on the second half of the sixteenth century. Avner Levi, "The First Translation of the Shulhan Arukh into Ladino," [Hebrew] in History and Creativity, ed. Tamar Alexander et al. (Jerusalem: Misgav Yerushalayim, 1994), 56-57. Thus, it is not surprising that the book Meza de el Alma, which presents halakhic contents in Ladino language, lead to controversy in the community of Salonika prior to its publication. See more details about this controversy in Levi, there, 61-64.

10 The translation of Orah Hayim and Yoreh De'ah is relatively detailed, whereas the translation of Even Ha-Ezer and Hoshen Mishpat is very brief. See Ora (Rodrigue) Schwarzwald, "Ladino Instructions in Meza de el Alma and Seder Nashim from Thessaloniki in the 16th Century," in Around the Point: Studies in Jewish Literature and Culture in Multiple Languages, ed. Hillel Weiss, Roman Katsman and Ber Boris Kotlerman (Newcastle Upon Tyne: Cambridge Scholars Publishing, 2014), 122-33. See also Ora (Rodrigue) Schwarzwald, "The Hebrew Component in the Ladino of Two Books by the Same Author," [Hebrew] in Nit'e Ilan: Studies in Hebrew and Related Fields Presented to Ilan Eldar, ed. Moshe BarAsher and Irit Meir (Jerusalem: Carmel, 2014), 400-1. See also Cohen, "The Ladino Bookshelf," 178 .

11 The similitude between the two texts, led Amzalak to the wrong conclusion that they were in fact the same book. See Moses Bensabat Amzalak, A tradução espanhola do livro de Joseph Caro [Shulhan ha-panim] feita por Mosé Altarás sob a denominação de "Libro de Mantenimiento de la Alma" (Lisbon: Of. Grâf. do Museu Comercial de Lisboa, 1927).

12 In spite of the original author's injunction that the book should never be printed in Latin letters. See Robert Singerman, Jewish Translation History (Amsterdam: J. Benjamin, 2002), 326. 
the author also clarifies that he will mainly deal with the precepts and will only include some, but not all, of the dinim (the details of the laws).

During 1627 , the same year that Athias published his first edition in Venice, Abraham Pharar published a similar text in Amsterdam. While written in Portuguese, his book also focused on the 613 precepts. Like Athias, he also decided to use Maimonides's enumeration; however, he also included a table where he categorized the precepts according to the parshiyot (the weekly Torah reading). This encouraged his readers to learn the precepts corresponding to the weekly Torah reading.

In spite of the fact that Menasseh ben Israel's Thesouro dos Dinim was not the first vernacular manual on Jewish practice written in the Western Sephardic diaspora, it was the first halakhic text that focused on the dinim and pretended to be an original text rather than a literary translation of the Shulhan Arukh. It was the first, but not the last. In 1668, David Pardo, at the time a cantor in London's Portuguese community, published a halakhic work entitled Compendio de Dinim que todo Israel Deve saber y Observar ${ }^{13}$ in Amsterdam. Some years later, in 1671, Hakham Abraham Vaez of Kaal Nefuzot Yehuda of Bayonne published the Arbol de vidas en el qual se contiene los Dinim más necesarios que debe observar todo Ysrael, presumably in Amsterdam. ${ }^{14}$

\section{The Halakhic Status of Former Anusim-Historical Background}

As previously noted, the Thesouro dos Dinim is not an original halakhic work, but an adapted version of the Shulhan Arukh, the main aim of which was to teach the Jewish Law to the former New Christians in order to facilitate their social and religious integration into the normative Jewish community of Amsterdam. In spite of the fact that Menasseh ben Israel did not at any time manifest either an intention to define the halakhic status of the former anusim or pretend to innovate in any of the many relevant particular halakhic aspects, I suggest that a detailed analysis of the Thesouro dos Dinim may lead us to an interesting understanding of the social reality of the New Jews in Amsterdam during the seventeenth century.

13 David Pardo, Compendio de Dinim que todo Israel Deve saber y Observar. Compuesto por estilo fácil y Breve (Amsterdam, 1669).

14 Abraham Vaez (del Kaal de Nefuzot Yehuda, Bayona) Arbol de vidas en el qual se contiene los Dinim más necesarios que debe observar todo Ysrael. Sacados de Varios y Graves autores (Amsterdam?, 1671). 
In order to understand the relevant background and the peculiarities of Menasseh ben Israel's statements, I will present a brief summary of the development of the former-anusim's halakhic status in historical perspective.

The question of the halakhic status, as well as other halakhic issues related to the conversos and former conversos in the peculiar circumstances in Spain between 1391 and 1492 (and even in earlier times), and afterwards among the Sephardic diaspora, was without doubt a topic that occupied the religious leaders of the day. Moreover, many important modern studies have addressed this particular aspect in the cultural history of the Sephardic diaspora. ${ }^{15}$

However, it is fundamental to distinguish the different circumstances among the diversity of communities, as well as the different periods in which the halakhic status of the former conversos was discussed. It is not surprising that most of the modern studies in fact refer to the rabbinical responsa produced between the fifteenth and the sixteenth centuries, close to the mass conversions and expulsions. But was the same law, ruled out for a person who converted to Christianity and returned to a Jewish community during his lifetime, applicable to the case of the conversos who joined a Jewish community in Amsterdam or other western cities more than a century later and after having been disconnected from normative Judaism for generations? Moreover, the great mass of this halakhic literature refers to status of the anusim in specific situations or contexts such as inheritance, wine trade, issues related to family law (divorce, levirate marriage, etc.), ${ }^{16}$ while they were still living in Lands of Idolatry.

15 See for example, Benzion Netanyahu, The Marranos of Spain-From the Late 14th to the Early 16th Century, according to Contemporary Hebrew Sources, 3rd ed. (Ithaca and London: Cornell University Press, 1999); Moisés Orfali, Los conversos españoles en la literature rabinica-Problemas jurídicos y opiniones legales durante los siglos XII-XVI (Salamanca: Universidad Pontificia de Salamanca: Universidad de Granada: Federacion Sefardí de España, 1982); Simon Schwarzfuchs, "Le Retour des Marranes au Judaïsme dans la littérature rabbinique," Xudeus e Conversos na Historía 1 (1994): 339-48; Elias Lipiner, "Spanish and Portuguese Conversos Facing Halakhic Problems," [Hebrew] in Portuguese Jewry at the Stake, ed. Yom Tov Asis and Moisés Orfali (Jerusalem: Magnes Press, 2009), 127-42; Alisa Meyuhas Ginio, "La actitud de los rabinos sefaradíes del imperio Otomano ante los conversos: el caso del Yavam Mesummad," in La mujer judía, ed. Yolanda Moreno Koch (Córdoba: Ediciones El Almendro, 2009), 129-48; Dora Zsom, "The Return of the Conversos to Judaism in the Ottoman Empire and North-Africa," Hispania Judaica Bulletin 7 (2010): 335-47; Juan Bejarano-Gutiérrez, "Rabbinic Responsa and the Jewish Status of Conversos," Journal of Spanish, Portuguese, and Italian Crypto Jews 4 (2012): 35-44; Matt Goldish, "Hakham Jacob Sasportas and the Former Conversos," Studia Rosenthaliana 44 (2012): 149-72.

16 For example, Orfali presents some cases of these and other issues from earlier sources until the sixteenth century. See Orfali, Los conversos españoles, 1-28; Meyuhas Gino 
The most important and influential precedent for the definition of the halakhic status of the conversos were Maimonides's writings and in particular his Iggeret ha-Shemad. ${ }^{17}$ In this epistle Maimonides sent a detailed answer to a group of Jews who were forced to convert to Islam. His halakhic conclusions in this text were: ${ }^{18}$ first, individuals who convert to another religion in times of persecution did not accomplish the mitsvah of kiddush ha-shem, ${ }^{19}$ but nor are they are blamed of hillul ha-shem; ${ }^{20}$ second, if one is obligated to convert to another religion but the conversion implies only a verbal compromise and not acts, and it is possible to keep the Jewish precepts in secret, this is a legitimate way to confront this historical situation. And if a religious authority is asked for advice in this situation, he should counsel the conversion and not the martyrdom; ${ }^{21}$ third, in this situation there is no blame placed on the person that converted to another religion, but only if he violates the Sabbath without being obligated to do so; ${ }^{22}$ fourth, in this situation the obligation of the individual is to keep the tradition and the laws as much as he can. And in the event that he violated a specific law, he should keep all the others (even if it seems to him as less important than those which he has violated); ${ }^{23}$ lastly, this situation is legitimate only in so far as he was unable to leave the lands of persecution. The individual is obligated to move to another place where he will be able to fully practice Judaism at the first opportunity, and if he decides to stay by his own choice, he is then considered to be mehalel ha-Shem. ${ }^{24}$

In contrast to Maimonides's epistle, most of the halakhic literature after the mass conversion in Spain in 1391 and the expulsion in 1492 focused on specific matters. However, it is also true that the general question of the Jewishness of

focuses her study on the laws of levirate marriage in the Ottoman Empire, see Mayuhas Gino, "La actitud de los rabinos sefaradies," 129-48.

17 See an English translation of the epistle, Maimonides, Crisis and Leadership: Epistles of Maimonides, trans. Abraham Halkin, with discussion by David Hartman (Philadelphia: Jewish Publication Society of America 1985), 15-45. Among the many studies on this text, see two different approaches: ibid., discussion by David Hartman, 46-90; Haym Soloveitchik, "Maimonides' Iggeret ha-Shemad: Law and Rhetoric," Collected Essays (Oxford: Littman Library of Jewish Civilization 2014), 2:288-330; and Soloveitchik, "Response to David Hartman," ibid., 331-37.

18 This numeration was added by the article's author in order to emphasis the main points, but is not found in Maimonides original text.

19 Sanctify the name of God (martyrdom).

20 Profane the name of God; Maimonides, Iggrot ha-Rambam (Jerusalem: Mosad HaRav Kook, 1960), 58-59.

21 Ibid., 61-62.

22 Ibid.

23 Ibid., 62-63.

24 Ibid., 64-66. 
the later generations of anusim might be found in a few places. For example, Rashbash (Rabbi Shimon ben Shelomo Duran, 1361-1444), stated that the general presumption should be that the conversos did not marry Gentiles and that the mother of a returning converso was of Jewish descent. ${ }^{25}$ But was this presumption applicable more than two centuries later? According to Rashbash, as long as their origin can be traced to a Jewish mother, albeit a converted one, they must be considered members of the Jewish people and, as such, regarded as "our brethren."26 Keeping in mind the actual attitude of the Jewish communities two centuries later, we may infer that the main impact of Rashbash's responsa was his call to consider the anusim as a potential part of the Jewish people. In contrast, the requirement to verify the maternal Jewish line was not as much applied.

As far as I have been able to discover, there is no written record of a halakhic attempt to address and define the peculiar seventeenth-century phenomenon. It doesn't mean that the halakhic tradition was not taken into account. On the contrary, the main point is that only the existing law was considered, without taking into consideration the new historical context and reality. Goldish has already pointed out (referring to the Sasportas case) that "most of the precedents concerning the treatment of conversos came from the fifteenth or early sixteenth centuries, or even earlier. This anachronism has consequences in legal decisions because Sasportas and others [halakhic authorities] still appear to be deciding issues based on conditions that had changed significantly since the precedent cases were adjudicated." 27

As mentioned before, the concept of anusim is an old existing legal category that recognizes the special circumstances in times of persecutions. The central point of discussion, in older halakhic discussions as well as in the particular case of Iberian anusim, regards the point when the person can no longer be considered anus, because he could have left the dangerous place but didn't. ${ }^{28}$ From this halakhic perspective, the better sign of compromise with Judaism is the act of leaving the Lands of Idolatry and the will to join a normative Jewish community. One of the most representative texts that reflects the general positive rabbinical attitude regarding the reintegration of the conversos into normative Judaism is found in one of the assertions of the rabbinical judge Binyamin Zeev (Greece, sixteenth century), quoted by Zsom: "we consider them

25 Quoted and translated from Hebrew by Zsom, "Return of the Conversos," 346.

26 The text has been paraphrased and translated into English by Netanyahu, there, p. 45. See the original text in Hebrew, Rashbash, Responsa (Livorno,1742) 89: 17a.

27 Goldish, "Hakham Jacob Sasportas," 157.

28 See, for example, in Ribash, Responsa, 4, 1c. This position is very similar to Rambam's position in Iggeret ha-Shemad. 
[the anusim who stayed in Lands of Idolatry] Jews so that they return, lest we close the doors of repentance before them. But in the strict sense of the Law we should penalize them for staying there." However, it seems strange that this continued to be the focus of the halakhic discourse in the seventeenth century and not the challenge of the very Jewishness of a significant number of former New Christians, who had lived as Christians for over a century—during which time they did not necessarily practice endogamy or preserve the maternal lineage- and were integrated into the Jewish community.

In fact, during the seventeenth century, people coming from Spain and Portugal who regarded themselves as anusim, were integrated into the Western Jewish community without any special theoretical discussion about their particular halakhic status. ${ }^{29}$ In an interesting article already mentioned above, Matt Goldish addressed the approach of Sasportas - one of the prominent rabbinical authorities in the seventeenth-century Western Sephardic diaspora-regarding the way to deal with conversos who had escaped the Iberian Peninsula and now wanted to join the Jewish community. From Goldish's article, it appears that, in contrast to other rabbinical authorities of these communities, this rabbi was particularly critical and severe in the way he conceived the process of return of the conversos to the bosom of normative Judaism. However, his criticism and rigidity had nothing to do with the maternal Jewish lineage of the conversos but with his expectation of an absolute compromise to the Jewish law and faith by the new Jews. As formulated by Goldish, "Sasportas's praise for returning conversos lasted only as long as those persons maintained a legally and theologically impeccable Jewish life."30

Thus, given the fact that the rabbinical authorities of the Western Sephardic diaspora did not openly discuss the peculiar halakhic situation of the seventeenth-century New Jews, let's try to understand their position from another perspective. What requirements did the religious authorities impose on those arriving from the Iberian Peninsula to join the Jewish community? Generally speaking, when a person arrived in the Western Sephardic diaspora communities an informal inquiry took place. The person was asked about his family, the specific place where he came from in Spain or Portugal, and sometimes people from the same native town recalled the newcomer's relatives whom they had known. On other occasions, the arrival of newcomers from Iberia

29 Zsom mentioned some halakhic questions regarding the Jewishness of the conversos found in the context of the responsa in the Ottoman Empire. However, this author did not prove the existence of any systematic inquiry prior to the integration in the community in this geographic area. See Zsom, "Return of the Conversos," 344-45.

Goldish, "Hakham Jacob Sasportas," 159. 
was an opportunity for community members to inquire about their own relatives who had remained in the Lands of Idolatry. However, it would be hard to characterize this custom as a legal inquiry into the New Jews' Jewishness. These converso families had been living as Christians for over a hundred years. Although in specific areas some sort of endogamy was preserved, doubtless in many cases the Jewish maternal lineage was uncertain. This notwithstanding, on the one hand, proving this biological continuity was not a requirement for joining the community. On the other hand, the inclusion of the newcomers, at least the male ones, was not automatic but included a defined rite of passage - circumcision (even those who were already circumcised had to spill a symbolic drop of blood, a process known as hatafat dam). As Kaplan and other scholars have noted, this rite had tremendous importance in its historical context. ${ }^{31}$ However, and in spite of the fact that circumcision is part of the Jewish conversion rite, it is difficult to identify the performance of this rite with a formal conversion because the other elements in the conversion process, especially the immersion in the ritual bath, were not required.

As mentioned above, in spite of the disconnection of generations from normative Judaism, no formal inquiry about the maternal lineage was done as a requirement for the former conversos to join one of the Western Sephardic Jewish communities. Lipiner presented an interesting example, ${ }^{32}$ which should be understood as the exception that proves the rule. In the context of a halakhic inquiry that lasted for more than a decade during the first half of the seventeenth century regarding the right of inheritance of a man named Yaacov Penso who was a former converso and who arrived as a child from Portugal to Venice, several testimonies were collected in Venice and the Ottoman Empire (Istanbul), where he went to study Torah and became a renowned scholar. ${ }^{33}$ The inquest was trying to determine whether Yaacov's mother, who was born in and never left Portugal, was of Jewish origins (m'zera yisrael), in which case, Yaacov will inherit, together with the other sons of his father. Among the testimonies were contradictory versions about Yaacov's mother's origins. This example is extremely significant. On the one hand, these documents constitute conclusive proof that the religious leaders of the Sephardic diaspora communities were aware that not all the anusim in Spain and Portugal had kept a strict endogamous lineage. On the other hand, it draws attention to the fact that

31 Yosef Kaplan, "Attitudes towards Circumcision among the Early Modern Western Sephardim," [Hebrew] in From Sages to Savants—Studies Presented to Avraham Grossman, ed. Joseph Hacker, Yosef Kaplan and Benjamin Z. Kedar (Jerusalem: The Zalman Shazar Center for Jewish History, 2010), 353-89.

32 Lipiner, "Spanish and Portuguese Conversos," 138-40.

33 Simha Assaf, Be-Ohalei Ya'akov (Jerusalem: Mossad Harav Kook, 1965), 160. 
this kind of inquiry, namely, a search of the mother's lineage, was not a matter of routine when a former converso joined the Jewish community, but it took place only in specific and special instances (that were the great minority of the cases), as in the above-mentioned case when an inheritance issue was to be determined. At the time the inquiry began, Yaacov Penso was already living and known as a Jew for many years and never before was he, or any other member of his family, questioned about their maternal lineage.

\section{$3 \quad$ Menasseh ben Israel's Attitude toward Anusim and Former Anusim}

Menasseh ben Israel wrote his practical compendium for a specific audience. He explicitly declared that it was written for the new members of his community who were willing to learn and adopt Jewish law, but couldn't read Hebrew. He wrote it for them, but he had no intention of composing a new guide for the New Jews; rather, he wished to translate the extant, black letter law for them. For that reason, nowhere in his work did he provide a halakhic definition of the New Jews' status. Consequently, in order to understand his position, we will need to extricate it from different parts of his work, building a comprehensive picture from a plethora of different contexts.

Menasseh ben Israel translated the concepts anus and ger as "forçado" and "peregrino," respectively. Regarding the concept "forçado," the author did not maintain his clinical, scholarly distance, but several times became emotionally involved, applying this concept to his own historical reality. In contrast to Yosef Caro, for whom the meaning of the concept was obvious, the first time our author used it, he added a short explanation: "Os forçados, e saõ os que foraõ por força mudados a outra religiaō e vivẽ donde naõ podẽ obseruar a sua" (the forced, that is to say, those who were obligated to adopt another religion and lived where he could not observe his own faith). This notwithstanding, it seems like Menasseh only applied this concept to those who still remained in Spain or Portugal. Once they moved to free lands, this term was evidently not relevant since they were no longer "forced."

Furthermore, Menasseh appears to have had a very negative opinion of the contemporary anusim and his halakhic rulings on this subject were much more stringent than those of the halakhic authorities he was reflecting. For example, the Shulhan Arukh (Yoreh De'ah § 124:9) discusses the anusim's wine and concludes that since they cannot avoid non-Jewish touch, their wine cannot be trusted, but they can be trusted as intermediaries in the kosher wine trade. Rema (Rabbi Moses Isserles), commenting on this law, debated whether 
the anusim's touch makes wine impure or not. Rema distinguished between two different kinds of anusim: those who violate the law in public, but not in private, and those who violate the law in both. Rema rules that the former's touch does not taint the wine, but the latter's does. According to Rema, those anusim who postponed their departure from the lands where they were under duress for economic reasons were appointed among those whose touch did not taint the wine, in other words, according to Rema, economic reasons were legitimate reasons to remain, at least temporarily in the Lands of Idolatry.

Menasseh ben Israel included Rema's commentary but omitted this permissive ruling, stating that remaining in enemy lands can only be legitimized if an individual has made every possible effort to leave and move to a place when he can freely observe all the laws without exception. From this we may infer that according to Menasseh ben Israel, even those anusim who only violate the law in public - but won't leave the oppressive lands despite the fact that they could - also taint the wine. According to Lipiner, the religious leaders of the time ${ }^{34}$ adopted an innovative and more permissive position about the anusim who remained in Lands of Idolatry, considering it a justified situation, even when they only adopted a partial observance of the Jewish law, as best they can ("kefi yekholtam"). ${ }^{35}$ This affirmation may reflect the opinion of some specific religious leaders, but it seems to be irrelevant to generalize as if it was the universally accepted halakhic position among the rabbis of the communities that received and absorbed former conversos. For instance, Menasseh ben Israel's text reflects a much severer position toward those anusim who remained in the Lands of Idolatry, indifferent to whether they partially observed Jewish Law or not. In addition, Lipiner's opinion seems to be mainly founded on the responsa of Rashbash and of Jachin ve-Boaz, but it must be taken into account that Rashbash lived in Spain even before the institution of the Inquisition and the expulsion, and the Jachin ve-Boaz responsa was written in North Africa during the fifteenth century. Evidently these books refer to a halakhic view that reflect a very different historical circumstance.

Both Rema and Menasseh ben Israel discuss anusim again when they address the subject of martyrology, that is to say, cases in which a person should refuse to transgress halakha even at the risk of losing his life. Both authors agree that in such a situation, those who transgress are considered under duress and, therefore, are exempt from punishment despite having profaned God's name. Both agree that if someone transgresses when he could have escaped, then the sin is considered intentional, and the sinner is deemed an intentional sinner.

34 It is not clear what are the chronological and the geographical limits of Lipiner's affirmation.

35 Lipiner, "Spanish and Portuguese Conversos," 137. See also n. 19, there. 
Here, there is no discrepancy between the two authors regarding the law; ${ }^{36}$ however, Menasseh added a passage that is even more extreme in its criticism of this phenomenon: "e tal se chama voluntario idolatra, e he privado da Gloria do outro mundo, e sera condenado ao infimo lugar do inferno" (this is a person who idolizes by choice, and will be deprived of the glory of the other world, and shall be condemned to the lowest place of hell). ${ }^{37}$

Menasseh ben Israel was extremely critical of the Spanish and Portuguese anusim who remained in the Lands of Idolatry, given that, in his opinion, there was no excuse to remain since they all could have moved and joined a normative Jewish community. ${ }^{38}$ However, just as he was critical of those who stayed, he was also extremely anxious to embrace those who left. An interesting and subtle example of this tendency is found in his halakhic discourse on abandoned babies. In the Shulhan Arukh, Even ha-Ezer $§ 4: 33$, Yosef Caro rules on the legal status of an abandoned baby discovered in a place where Jews and nonJews live side by side. Caro rules that such a child will be considered non-Jewish by his contemporaries, that is to say, they will assume that his mother was not Jewish, but if he marries and divorces a Jewish woman, he will be required to write a writ of divorce (get) like a born Jew. (The reason for these two rulings goes unexplained in the Shulhan Arukh, but they are promulgated to avoid creating mamzerim. ${ }^{39}$ ) Menasseh ben Israel included this regulation in his work and remained quite faithful to his source, the Shulhan Arukh, but in contrast to the aforementioned examples, here he omitted Rema's commentary.

While it is true that Menasseh ben Israel did not always include Rema's opinion and that his primary loyalty lay with Caro, in this opportunity he chose to mention a case by Rema, and which Caro had ignored, that was extremely

36 According to Lipiner it was common among the instructors of the former conversos willing to join a Jewish community, to carry out an investigation in order to determine whether the returnees in fact did everything in their power to escape from the lands of idolatry at the first opportunity. Lipiner, "Spanish and Portuguese Conversos," 131. Regrettably the author did not quote any specific case or source nor the time or place were those inquiries occurred. As far as I know there is no evidence of similar trends among the instructors in the community of Amsterdam.

37 Thesouro dos Dinim, Part. II, Cap. XXI, 3.

38 At the time of the expulsion not everyone who opted to leave the Iberian Peninsula was as critical, but some even justified the decision of individuals to remain under certain terms. See, for example, Shelomo Ibn Verga, Shevet Yehuda, ed. Azriel Schochat (Jerusalem: Mosad Bialik, 1947), 56. More about Ibn Verga's perspective about conversos and conversion, see Jeremy Cohen, A Historian in Exile-Solomon ibn Verga, Shevet Yehuda, and the Jewish-Christian Encounter (Philadelphia: University of Pennsylvania Press, 2017), 134-49. Bastard is the translation of the word mamzer in Christian Scripture; the Hebrew Biblical meaning is more complex and refers to a child born of sexual relations forbidden in the Torah, as in Leviticus 18, and Deuteronomy 23. 
relevant to his particular historical reality: Rema states that "it is permissible to marry the anusim that came back to the religion of Israel [that is to say, they are not to be deemed potential mamzerim] in the same way that is permissible to marry any other convert person." It seems strange that Menasseh ben Israel decided not to include this ruling. From a practical point of view, it would have facilitated and legally justified the smooth integration of his audience into the Jewish community. Why, then, did he omit this comment? I would suggest that he probably did so for a personal, not a practical, reason. Rema's comment overcomes a legal challenge, but it does so by comparing and even equating the legal status of the anusim who returned to Judaism to that of a non-Jew who converted. Would Menasseh ben Israel have agreed with Rema's legal reasoning? We cannot know for sure, but probably yes. But in a public work he was loath to make such a comparison. The conversos could not be merely referred to as gerim.

It appears, however, that Menasseh ben Israel demonstrated this kind of sensibility in discussing "converts," in general. For example, citing from an extensive list of rules in the Shulhan Arukh (Even ha-Ezer, chapter 4) concerning permitted and prohibited marriages and mamzerim, Menasseh decided to include the one expressing the most positive sentiments toward converts: the one that states that the progeny of a marriage between a Jew and a converted woman or between a Jewess and a converted man has the same legal status as the progeny of a Jew and a Jewess. ${ }^{40}$ Furthermore, he omitted other clauses that deemed the converts' legal status inferior, such as the rule that a mamzer may not marry a Jew, but he may marry a convert or a freed slave. ${ }^{41}$ Indeed, Menasseh ben Israel's omission of Caro's ruling that a sterile person may marry a convert or a freed slave is even more striking, as he includes Caro's ruling that prohibits marriage with a sterile person, which appears in the same sentence in the Shulhan Arukh. ${ }^{42}$

Do these examples reflect an inherently positive and cautious treatment of the concept of ger, irrespective of Menasseh ben Israel's historical context, or does this ambiguous attitude reflect his period? From one perspective, the conversos who adopted Judaism were seen as a legitimate link in the Jewish chain, but from another one they had a lot in common with the ger, especially during their process of integration into the Jewish community, so his positive treatment of the ger may reflect this reality.

$40 \quad$ Shulhan Arukh, Even ha-Ezer, § 4:23; Thesouro dos Dinim, Part IV, Cap. XXviI, 7 .

41 Shulhan Arukh, Even ha-Ezer, § 4:22.

42 Ibid., § 5:1; Thesouro dos Dinim, Part IV, Cap. XXviI, 10. 
As mentioned before, Menasseh ben Israel avoided creating a new or independent legal category for the New Christians who adopted Judaism and became New Jews, despite the peculiarity of this phenomenon and the fact that the Thesouro dos Dinim specifically addressed this public. However, the author wished to write a practical guide that would be as useful as possible for his readers, so it seems that on several occasions, he did use the term "peregrino," and he did mention some halakhic resolutions that talk about the ger in reference to the new emigrants from Spain and Portugal. Let's examine a representative example.

The Shulhan Arukh is a longer and far more detailed work than the Thesouro. Menasseh ben Israel addresses many subjects, some more comprehensively and some more superficially. One of the subjects he addresses in a manner that is significantly briefer and more concise than Caro's discussion is idolatry. The Shulhan Arukh in Yore De'ah dedicates twenty chapters and hundreds of rules to this subject. ${ }^{43}$ While the Thesouro did not omit this subject entirely, it covers it in three short chapters that contain only a few rules, mainly those regulating prohibited images and superstitions. Among the selected items, Menasseh included a ruling that addresses the unique case of two brothers, one an idolater and the other a ger, who inherit their idolater father's estate. The clause dictates that if the ger has not yet taken physical possession of the objects, he may make a deal with his brother exchanging the idolatrous ones for permitted ones.

Why, among hundreds of rules, did Menasseh ben Israel decide to include precisely this one? We are aware of few cases of converts who lived in Amsterdam, but it seems more likely that he was addressing the many readers likely to find themselves in a similar situation. Many of them had Christian relatives still living in Spain or Portugal, so it seems very likely that inheritance questions were common. Menasseh wanted to stay within Caro's framework and was not willing to add a special rule for Jews (or former anusim) who inherited the estates of their non-Jewish parents, but he decided to leave Caro's formulation as it was. Caro was discussing converts, not Jews or former anusim. However, apparently this distinction did not bother Menasseh when he felt it was necessary to teach an important lesson to the members of his community.

Like other contemporary rabbis, Menasseh ben Israel did not define the halakhic status of his community members. In fact, the main value to be found in the Thesouro dos Dinim is not an innovative halakhic attitude but an interesting and significant example of a social attitude of the time toward the former 
anusim who were joining the Jewish community in Amsterdam and toward those anusim who still remained in the Lands of Idolatry. From the examples mentioned above it seems very likely that Menasseh ben Israel considered the New Jews, former anusim who had returned to normative Judaism; he harshly criticized those who remained in the Lands of Idolatry, apparently continuing Maimonides's opinion, and warmly welcomed those who joined the Jewish community, apparently without obligating them to prove their Jewish origins despite the generations of disconnection. He did not refer to them, even indirectly, as converts. However, he did find himself, on more than one occasion, using the concept of "converts" in an ambiguous way, without clearly distinguishing between the halakhic implications that being a former anus and being a convert might have.

\section{Bibliography}

Amzalak, Moses Bensabat. A tradução espanhola do livro de Joseph Caro [Shulhan hapanim] feita por Mosé Altarás sob a denominação de "Libro de Mantenimiento de la Alma." Lisbon: Of. Grâf. do Museu Comercial de Lisboa, 1927.

Assaf, Simha. Beoholei Ya'akov. Jerusalem: Mossad Harav Kook, 1965.

Bejarano-Gutiérrez, Juan Marcos. "Rabbinic Responsa and the Jewish Status of Conversos." Journal of Spanish, Portuguese, and Italian Crypto Jews 4 (2012): 35-44.

Cohen, Dov ben David. "The Ladino Bookshelf: Research and Mapping." [Hebrew] PhD diss., Bar-Ilan University, 2011.

Cohen, Jeremy. A Historian in Exile - Solomon ibn Verga, Shevet Yehuda, and the JewishChristian Encounter. Philadelphia: University of Pennsylvania Press, 2017.

Cohen, Matty. "A Diachronic and Synchronic Reconsideration of the Term Ger in the Bible." [Hebrew] In Proceedings of the World Congress of Jewish Studies 10: A, 11-8. Jerusalem 1989.

Dan, Joseph. "Menasseh ben Israel: Attitude Towards the Zohar and Lurianic Kabbalah." In Menasseh ben Israel and His World. Edited by Yosef Kaplan, Henry Méchoulan, and Richard H. Popkin, 199-206. Leiden: Brill, 1989.

Goldish, Matt. "Hakham Jacob Sasportas and the Former Conversos." Studia Rosenthaliana 44 (2012): 149-72.

Hartman, David. Crisis and Leadership: Epistles of Maimonides. Translated by Abraham Halkin. Philadelphia: Jewish Publication Society of America 1985.

Kaplan, Yosef. "Attitudes toward Circumcision among the Early Modern Western Sephardim." In From Sages to Savants_Studies Presented to Avraham Grossman. [Hebrew] Edited by Joseph Hacker, Yosef Kaplan, and Benjamin Z. Kedar, 353-89. Jerusalem: Zalman Shazar Center, 2010. 
Kasher, Asa. "How Important was Menasseh ben Israel?" In Menasseh ben Israel and His World. Edited by Yosef Kaplan, Henry Méchoulan, and Richard H. Popkin, 22027. Leiden: Brill, 1989.

Levi, Avner. "Shulhan Arukh First Translation into Ladino." [Hebrew] In History and Creativity. Edited by Tamar Alexander, Abraham Haim, Galit Hazan-Rokem, and Ephraim Hazan, 55-71. Jerusalem: Misgav Yerushalaim, 1994.

Lipiner, Elias. "Spanish and Portuguese Conversos Facing Halakhic Problems.” (Hebrew). In Portuguese Jewry at the Stake. Edited by Yom Tov Asis and Moisés Orfali, 127-42. Jerusalem: Magnes Press, 2009.

Meyuhas Ginio, Alisa. "La actitud de los rabinos sefaradíes del imperio Otomano ante los conversos: el caso del Yavam Mesummad." In La mujer judía. Edited by Yolanda Moreno Koch, 129-48. Córdoba: Ediciones El Almendro, 2009.

Netanyahu, Benzion. The Marranos of Spain-From the Late 14th to the Early 16th Century, According to Contemporary Hebrew Sources. Third Edition, Updated and Expanded. Ithaca and London: Cornell University Press, 1999.

Orfali, Moisés. Los conversos españoles en la literatura rabínica-Problemas jurídicos y opiniones legales durante los siglos XII-XVI. Salamanca: Universidad Pontificia de Salamanca, Universidad de Granada, Federación Sefardí de España, 1982.

Rauschenbach, Sina. "Mediating Jewish Knowledge: Menasseh ben Israel and the Christian Respublica litteraria." Jewish Quarterly Review 102, no. 4 (2012): 561-88.

Rokeah, David. "The Jewish Conversion in Antiquity, Theory and Practice." Beit Mikra: Journal for the Study of the Bible and Its World 4ob (1995): 135-52.

Schiffman, Lawrence H. "Conversion to Judaism in Tannaitic Halakhah." In Conversion, Intermarriage, and Jewish Identity. Edited by Adam Mintz and Marc D. Stern, 189215. New York: The Michael Scharf Publication Trust of the Yeshiva University Press, 2015 .

Schwarzfuchs, Simon. "Le Retour des Marranes au Judaïsme dans la littérature rabbinique." Xudeus e Conversos na Historía 1 (1994), 339-48.

Schwarzwald, Ora. "Ladino Instructions in Meza de el Alma and Seder Nashim from Thessaloniki in the 16th Century." In Around the Point: Studies in Jewish Literature and Culture in Multiple Languages. Edited by Hillel Weiss, Roman Katsman and Ber Boris Kotlerman, 122-33. Newcastle Upon Tyne: Cambridge Scholars Publishing, 2014.

Schwarzwald, Ora. "The Hebrew Component in the Ladino of Two Books by the Same Author." [Hebrew] In Nit'e Ilan: Studies in Hebrew and Related Fields Presented to Ilan Eldar. Edited by Moshe Bar-Asher and Irit Meir, 153-91. Jerusalem: Carmel, 2014. Singerman, Robert. Jewish Translation History. Amsterdam: J. Benjamin, 2002.

Zsom, Dora. "The Return of the Conversos to Judaism in the Ottoman Empire and North-Africa." Hispania Judaica Bulletin 7 (2010): 335-47. 